\title{
KONSEP PERLINDUNGAN HUKUM TERHADAP BURUH YANG MENDAPATKAN PEMUTUSAN HUBUNGAN KERJA AKIBAT COVID-19
}

\author{
1Suci Mahara, ${ }^{2}$ Malahayati, ${ }^{2}$ Hasan Basri \\ Co. Author Email : Malahayati@unimal.ac.id \\ ${ }^{1}$ Mahasiswa Fakultas Hukum Universitas Malikussaleh \\ ${ }^{2}$ Dosen Fakultas Hukum/Universitas Malikussaleh
}

\begin{abstract}
The entry of Corona Virus Disease (Covid-19) in early March 2020 to Indonesia, forced companies / employers to forcibly lay off workers / laborers due to the non-operation of the company and obeying the regulations issued by the government regarding the prohibition of gathering and maintaining distance from each other. The formulation of the problem in this research is the concept of legal protection for workers who have been laid off due to Covid-19 which is reviewed through Law Number 13 of 2003 concerning Manpower and Law Number 11 of 2020 concerning Job Creation. The purpose of this study is to describe and provide an overview of legal protection for workers who have been laid off due to this pandemic. This research method is a qualitative method with a normative form of research that puts laws or rules to answer the problems to be studied. The approach in this research comes from statutory regulations and literature study. Based on the results of this study, the concept of legal protection for workers who were laid off due to Covid-19 which was reviewed through the Manpower Act is based on Pancasila which includes legal protection for wages, welfare and social security for workers and the concept of legal protection for workers who have been laid off as a result of Covid-19 based on the Job Creation Law, namely equal justice by giving severance pay as the fulfillment of labor rights. This study advises the government to include specific rules regarding legal protection for workers who have been laid off due to disease outbreaks and advises employers / employers to include the rights that workers need in the work agreement if a forced layoff occurs.
\end{abstract}

Key Words: Legal Protection, Covid-19, PHK. 


\section{PENDAHULUAN}

Indonesia merupakan negara hukum yang telah tertuang dalam Undang-Undang Dasar 1945 Pasal 1 ayat (3), maka segala sesuatu ada hukum yang mengaturnya. Tidak hanya mengatur, namun hukum juga memberi manfaat dan perlindungan kepada masyarakatnya. Negara hukum sendiri berdiri di atas hukum yang menjamin keadilan bagi seluruh warga negara.

Fitzgerald mengutip istilah perlindungan hukum dari Salmond bahwa hukum bertujuan mengintegrasikan dan mengkoordinasikan berbagai kepentingan dalam masyarakat karena dalam suatu lalu lintas kepentingan, perlindungan terhadap kepentingan tertentu dapat dilakukan dengan cara membatasi berbagai kepentingan dilain pihak. Kepentingan hukum adalah mengurusi hak dan kepentingan manusia, sehingga hukum memiliki otoritas tertinggi untuk menentukan kepentingan manusia yang perlu diatur dan dilindungi. Perlindungan hukum harus melihat tahapan yakni perlindungan hukum lahir dari suatu ketentuan hukum dan segala peraturan hukum yang diberikan oleh masyarakat yang pada dasarnya merupakan kesepakatan masyarakat tersebut untuk mengatur hubungan perilaku antara anggota-anggota masyarakat dan antara perseorangan dengan pemerintah yang dianggap mewakili kepentingan masyarakat. ${ }^{1}$

Pada bulan Desember 2019, dunia digemparkan dengan merebaknya virus baru yaitu corona virus jenis baru (SARS-CoV-2) dan penyakitnya disebut Corona Virus Disease (Covid-19), kasus pneumonia misterius ini pertama kali dilaporkan di Wuhan, Provinsi Hubei, Tiongkok. Kasus pertama dikaitkan dengan pasar ikan di Wuhan. Sejak tanggal 31 Desember 2019 hingga 3 Januari 2020 kasus ini meningkat pesat, ditandai dengan dilaporkannya sebanyak 44 (empat puluh empat) kasus. Tidak sampai satu bulan, penyakit ini telah menyebar di berbagai provinsi lain di China, Thailand, Jepang, dan Korea Selatan. Virus ini dapat ditularkan dari manusia ke manusia dan telah menyebar secara luas di China dan lebih dari 190 negara dan teritori lainnya. ${ }^{2}$

Corona virus pun menyebar ke Indonesia pada awal maret diawali dengan dua kasus yang positif terjangkit virus corona. Pada 12 Maret 2020, WHO mengumumkan Covid-19 sebagai pandemi. Hingga tanggal 29 Maret 2020, terdapat 634.835 kasus dan 33.106 jumlah kematian di seluruh dunia. Sementara di Indonesia sudah ditetapkan 1.528 kasus dengan positif Covid-19 dan 136 kasus kematian. Sampai saat ini 23 September 2020 telah tercatat 257.388 kasus yang positif terjangkit virus corona dan 9.837 dinyatakan meninggal dunia. ${ }^{3}$ Adanya virus ini menyebabkan pemerintah mengeluarkan peraturan pemerintah larangan untuk berkumpul dan menjaga jarak satu sama lain atau pembatasan sosial berkala yang diatur dalam Peraturan Pemerintah Nomor 21 Tahun 2020 tentang Kebijakan Pembatasan Sosial Berskala Besar (PSBB) yang mengakibatkan pengurangan/penghentian aktifitas para pekerja/buruh. Sehingga para buruh harus diberhentikan atau di rumahkan secara terpaksa akibat tidak ber-operasionalnya perusahaan. Pemerintah berdasarkan data Kemnaker (Kementerian Ketenagakerjaan) tanggal 7 April 2020, terdapat 39.977 perusahaan yang melakukan PHK dan merumahkan 1.010.579

${ }^{1}$ Satjipto Raharjo, Ilmu Hukum, Citra Aditya Bhakti, Bandung, 2000, hlm. 53

2 Dewa Made Gum Setyadi, Pendampingan Upaya Pendekatan Ketaatan Masyarakat Terhadap Surat Edaran No. 434/572/DKIS/2020 Pembatasan Jam Operasional Di Desa Sidakarya, Jurnal Pengabdian Masyarakat, Vol. I, No. 3, hal. 160-166, Agustus 2020.

3 Dian Erika Nugraheny, Update 23 September: Ada 59.453 Kasus Aktif Covid-19 di Indonesia, (https://nasional.kompas.com/read/2020/09/23/16451261/update-23-september-ada-59453-kasus-aktifcovid-19-di-indonesia, di akses pada 23 September 2020). 
karyawan ${ }^{4}$. Keadaan yang memprihatinkan ini membuat kondisi ekonomi negara terancam dan demografi di Indonesia kembali melemah, karena banyak masyarakat Indonesia terpaksa menganggur dan sulit untuk kembali mencari pekerjaan dikarenakan PSBB yang diakibatkan oleh wabah virus corona ini.

Berdasarkan latar belakang yang telah dipaparkan, maka penulis dapat menarik sebuah permasalahan yakni bagaimana konsep perlindungan hukum terhadap buruh yang di PHK akibat Covid-19 dan analisis hukumnya berdasarkan Undang-Undang Nomor 11 Tahun 2020 tentang Cipta Kerja.

\section{METODE PENELITIAN}

Untuk menjawab permasalahan diatas, penulis menggunakan metode penelitian normatif atau doktrinal, yaitu penelitian hukum kepustakaan. Yang nantinya penulis akan meneliti melalui norma-norma dan sumber hukum yang ada, serta kajian para ahli. Sedangkan dilihat dari sifatnya jenis penelitian ini bersifat deskriptif analisis yaitu jenis penelitian yang berupaya untuk mendeskripsikan atau memberi gambaran yang utuh tentang konstruksi hukum dan pelaksanaan perlindungan hukum terhadap buruh yang mendapat pemutusan hubungan kerja akibat Covid-19 oleh instansi, perusahaan atau pemberi kerja, yang nantinya akan dianalisis menggunakan teori-teori hukum dan Undang-Undang Cipta Kerja serta aturan hukum lainnya. maka metode pendekatan yang digunakan adalah secara yuridis normatif yaitu pendekatan terhadap peraturan perundang-undangan serta teori-teori hukum. sumber data yang akan digunakan dalam melakukan penelitian ini adalah Penelitian kepustakaan (Library Research) yang bersumber pada bahan pustaka, buku atau literature yang berkaitan dengan masalah yang akan diteliti.

\section{HASIL PENELITIAN DAN PEMBAHASAN}

\section{Konsep Perlindungan Hukum Terhadap Buruh Akibat Covid-19 Menurut Undang-Undang Nomor 11 Tahun 2020 Tentang Cipta Kerja}

\section{a. Perlindungan Hukum Terhadap Buruh}

Menurut Setiono, perlindungan hukum adalah tindakan atau upaya untuk melindungi masyarakat dari perbuatan sewenang-wenang oleh penguasa yang tidak sesuai dengan aturan hukum, untuk mewujudkan ketertiban dan ketentraman sehingga memungkinkan manusia untuk menikmati martabatnya sebagai manusia. ${ }^{5}$

Konsep perlindungan hukum terhadap buruh yang di atur di dalam Undang-Undang Cipta Kerja tidak jauh berbeda dengan Undang-Undang Ketenagakerjaan. Hanya saja beberapa Pasal Undang-Undang Ketenagakerjaan di ubah oleh Undang-Undang Cipta Kerja. Beberapa Pasal di antaranya yaitu :

1. Pasal 88 ayat (1) "Setiap pekerja/buruh berhak atas penghidupan yang layak bagi kemanusiaan."

2. Pasal 88 ayat (2) "Pemerintah pusat menetapkan kebijakan pengupahan nasional sebagai salah satu upaya mewujudkan hak pekerja/buruh atas penghidupan yang layak bagi kemanusiaan."

${ }^{4}$ Ayomi Amindoni, Virus Corona Ditengah Pandemi Covid-19 Di Perkirakan Mencapai Puncak Bulan Juni, Kartu Prakerja Dianggap Tak Efektif (https://www.bbc.com /indonesia/ indonesia-52218475, Di akses pada 22 April 2020).

${ }^{5}$ Setiono, Rule Of Law, Magister Ilmu Hukum Program Pascasarjana Universitas Sebelas Maret, Surakarta, 2004, hlm. 3 
3. Pasal $88 \mathrm{~A}$ ayat (1) "Hak pekerja/buruh atas upah timbul pada saat terjadi hubungan kerja antara pekerja/buruh dengan pengusaha dan berakhir pada saat putusnya hubungan kerja."

4. Pasal 88A ayat (2) "Pengusaha wajib membayar upah kepada pekerja/buruh sesuai kesepakatan atau sesuai peraturan perundang-undangan."

5. Pasal 88A ayat (3) "Setiap pekerja/buruh berhak memperoleh upah yang sama untuk pekerjaan yang sama nilainya."

Secara garis besar dalam Undang-Undang Cipta Kerja kebijakan pengupahan terhadap buruh meliputi:

a. Upah minimum

b. Struktur dan skala upah

c. Upah tidak masuk kerja karena berhalangan

d. Upah tidak masuk kerja dan/atau tidak melakukan pekerjaan karena alasan tertentu

e. Upah sebagai dasar perhitungan atau pembayaran hak dan kewajiban lainnya.

Menteri Ketenagakerjaan (Menaker) Ida Fauziyah menyatakan bahwa Undang-Undang

Cipta Kerja mengatur syarat-syarat dan perlindungan hak bagi pekerja/buruh kontrak atau perjanjian kerja waktu tertentu (PKWT) yang menjadi dasar dalam penyusunan perjanjian kerja. Undang-Undang Cipta Kerja juga mengatur perlindungan tambahan berupa kompensasi kepada pekerja/buruh pada saat berakhirnya PKWT. Menaker Ida Fauziyah juga menambahkan bahwa Undang-Undang Cipta Kerja tetap mengatur hak-hak dan perlindungan upah bagi pekerja/buruh sebagaimana peraturan perundang-undangan yang ada (Undang-Undang Nomor 13 Tahun 2003 tentang Ketenagakerjaan dan Peraturan Pemerintah Nomor 78 Tahun 2015 tentang Pengupahan) dan selanjutnya akan diatur dalam Peraturan Pemerintah yang baru. ${ }^{6}$

\section{b. Peraturan Tentang Pemutusan Hubungan Kerja Menurut Undang-Undang Nomor 11 Tahun 2020 Tentang Cipta Kerja}

Pasal 150 Undang-Undang Cipta Kerja menyatakan bahwa pemutusan hubungan kerja dalam Undang-Undang ini meliputi pemutusan hubungan kerja yang terjadi di badan usaha yang berbadan hukum atau tidak, milik orang perseorangan, milik persekutuan atau milik badan hukum, baik milik swasta maupun milik negara, milik usaha sosial maupun usaha lain yang mempunyai pengurus dan mempekerjakan orang lain dengan membayar upah atau imbalan dalam bentuk lain. ${ }^{7}$

Undang-Undang Cipta Kerja mengubah ketentuan pengaturan yang mengatur pemutusan hubungan kerja (PHK) antara pengusaha dan pekerja/buruh. Pengubahan ketentuan itu di atur dalam Pasal 81 angka 37. Aturan ini mengubah ketentuan Pasal 151 Undang-Undang Nomor 13 Tahun 2003 tentang Ketenagakerjaan. Adapun pernyataan itu yakni pemutusan hubungan kerja dapat terjadi karena perusahaan melakukan penggabungan, peleburan, pengambil alihan atau pemisahaan perusahaan dan pekerja/buruh tidak bersedia melanjutkan hubungan kerja atau pengusaha tidak bersedia menerima pekerja/buruh. ${ }^{8}$

${ }^{6}$ Arnoldus Kristanus, Sanya di akses 27 Januari 2021) Dinda dan Novy Lumanaw, Menaker: UU Ciptaker Lindungi Pekerja, (https://investor.id/business/menaker-uu-ciptaker-lindungi-pekerja,

7 Mela Arnani, Beda Aturan PHK di UU Ketenagakerjaan dan Omnibus Law Cipta Kerja, (https://www.kompas.com/tren/read/2020/10/06/183000165/beda-aturan-phk-di-uu-ketenagakerjaandan-omnibus-law-cipta-kerja?page=all\#page2, di akses 28 Januari 2021).

8 Rina Anggraeni, UU Cipta Kerja Sah Berlaku, Ini Ketentuan PHK yang Diteken Jokowi, (https://ekbis.sindonews.com/read/218374/34/uu-cipta-kerja-sah-berlaku-ini-ketentuan-phk-yangditeken-jokowi- di akses 28 Januari 2021). 
Dalam Undang-Undang Cipta Kerja antara Pasal 154 dan Pasal 155, di sisipkan 1 (satu) pasal yaitu Pasal 154A yang menyatakan bahwa pengusaha/pemberi kerja dapat melakukan PHK kepada buruh dengan alasan berikut:

a. Perusahaan melakukan penggabungan, peleburan, pengambilalihan atau pemisahan perusahaan.

b. Perusahaan melakukan efisiensi.

c. Perusahaan tutup yang di sebabkan karena perusahaan mengalami kerugian.

d. Perusahaan tutup yang di sebabkan karena keadaan memaksa (force majure).

e. Perusahaan dalam keadaan penundaan kewajiban pembayaran utang.

f. Perusahaan pailit.

g. Perusahaan melakukan perbuatan yang merugikan pekerja.

h. Pekerja mengundurkan diri atas kemauan sendiri.

i. Pekerja mangkir.

j. Pekerja melakukan pelanggaran ketentuan yang diatur dalam perjanjian kerja, peraturan perusahaan atau perjanjian kerja sama.

k. Pekerja ditahan pihak berwajib.

l. Pekerja mengalami sakit berkepanjangan atau cacat akibat kecelakaan kerja dan tidak dapat melakukan pekerjaannya setelah melampaui batas 12 bulan.

m. Pekerja memasuki usia pensiun.

n. Pekerja meninggal dunia.

Di antara Pasal 151 dan Pasal 152 Undang-Undang Cipta Kerja, di selipkan 1 (satu) pasal dimana ada beberapa hal pengecualian pemutusan hubungan kerja yang boleh dilakukan oleh perusahaan terhadap buruh tanpa perlu adanya kesepakatan antara keduanya yaitu di atur dalam Pasal 151A yang berbunyi sebagai berikut:

Pasal 151A "Kesepakatan dalam pemutusan hubungan kerja sebagaimana dimaksud dalam Pasal 152 ayat (1) tidak di perlukan dalam hal:

a. Pekerja/buruh dalam masa percobaan kerja.

b. Pekerja/buruh melakukan pelanggaran ketentuan yang di atur dalam perjanjian kerja, peraturan perusahaan, atau perjanjian kerja bersama dan telah diberikan surat peringatan pertama, kedua dan ketiga secara berturut-turut.

c. Pekerja/buruh mengundurkan diri atas kemauan sendiri.

d. Pekerja/buruh dan pengusaha berakhir hubungan kerjanya sesuai perjanjian kerja waktu tertentu.

e. Pekerja/buruh mencapai usia pensiun sesuai dengan perjanjian kerja, peraturan perusahaan, atau perjanjian kerja bersama.

f. Pekerja/buruh meninggal dunia.

g. Perusahaan tutup yang disebabkan karena keadaan memaksa (force majeure).

h. Perusahaan dinyatakan pailit berdasarkan putusan pengadilan niaga."

Berdasarkan uraian di atas, apabila perusahaan melakukan pemutusan hubungan kerja dengan alasan-alasan tersebut, maka perusahaan atau pemberi kerja tidak perlu melakukan kesepakatan terhadap buruh. Artinya perusahaan atau pemberi kerja di beri kewenangan untuk melakukan pemutusan hubungan kerja terhadap buruh tanpa adanya kesepakatan dengan alasan-alasan pengecualian yang telah di atur di dalam Pasal 154A Undang-Undang Cipta Kerja tersebut. 


\section{c. Pencegahan Pemutusan Hubungan Kerja Terhadap Buruh Menurut Undang-Undang Nomor 11 Tahun 2020 Tentang Cipta Kerja}

Pasal 151 ayat (1) Undang-Undang Ketenagakerjaan yang menyatakan tentang pencegahan pemutusan hubungan kerja agar tidak terjadi telah di ubah oleh Undang-Undang Cipta Kerja sehingga Pasal 151 ayat (1) berbunyi : "Pemutusan hubungan kerja di laksanakan berdasarkan kesepakatan antara pengusaha dengan pekerja/buruh." Selanjutnya Pasal 151 ayat (2) Undang-Undang Cipta Kerja menyatakan bahwa "Dalam hal kesepakatan sebagaiman di maksud pada ayat (1) tidak tercapai, pemutusan hubungan kerja di lakukan melalui prosedur penyelesaian perselisihan hubungan industrial sesuai dengan ketentuan peraturan perundangundangan.

Menurut Surat Edaran Menteri Tenaga Kerja No : SE-907/MEN/PHI-PPHI/X/2004 tentang Pencegahan Pemutusan Hubungan Kerja Massal, apabila perusahaan mengalami kesulitan yang dapat membawa pengaruh terhadap ketenagakerjaan, maka pemutusan hubungan kerja haruslah merupakan upaya terakhir, setelah dilakukan upaya sebagai berikut:

a. Mengurangi upah dan fasilitas pekerja tingkat atas, misalnya tingkat manajer dan direktur

b. Mengurangi shift

c. Membatasi/menghapuskan kerja lembur

d. Mengurangi jam kerja

e. Mengurangi hari kerja

f. Meliburkan dan merumahkan pekerja/buruh secara bergilir untuk sementara waktu

g. Tidak atau memperpanjang kontrak bagi pekerja yang sudah habis masa kontraknya

h. Memberikan pensiun bagi yang sudah memenuhi syarat.

Pada masa pandemi Covid-19 ini, perusahaan haruslah mengambil kebijakan yang tepat agar tidak merugikan para buruh. Perusahaan dapat melakukan upaya-upaya di atas agar tidak terjadi pemutusan hubungan kerja atau perusahaan juga dapat melakukan upaya alternatif lainnya seperti merumahkan pekerja/buruh selama masa pandemi ini. Pada dasarnya istilah "merumahkan pekerja/buruh" tidak di atur secara khusus di dalam Undang-Undang Ketenagakerjaan maupun Undang-Undang Cipta Kerja. Namun hal tersebut di atur dalam Surat Edaran Menteri Tenaga Kerja No: SE-05/M/BW/1998 tentang Upah Pekerja yang Dirumahkan Bukan Kearah Pemutusan Hubungan Kerja.

Dalam SE Menaker 5/1998 tentang Upah pekerja yang Dirumahkan Bukan Kearah Pemutusan Hubungan Kerja tersebut menjelaskan bahwa sebagai upaya penyelamatan perusahaan yang mengalami kesulitan, maka ditempuh tindakan merumahkan pekerja/buruh untuk sementara waktu dengan ketentuan upah sebagai berikut :

a. Pengusaha tetap membayar upah secara penuh yaitu berupa upah pokok dan tunjangan tetap selama pekerja/buruh dirumahkan, kecuali telah di atur lain dalam perjanjian kerja, peraturan perusahaan atau kesepakatan kerja bersama.

b. Apabila pengusaha akan membayar upah pekerja tidak secara penuh agar dirundingkan dengan pihak serikat pekerja/buruh dan/atau para pekerja/buruh mengenai besarnya upah selama dirumahkan dan lamanya dirumahkan.

c. Apabila perundingan melalui jasa pegawai perantara ternyata tidak tercapai kesepakatan agar segera dikeluarkan surat anjuran. Apabila anjuran tersebut di tolak oleh salah satu atau kedua belah pihak yang berselisih, maka masalahnya agar segera dilimpahkan ke P4 Daerah atau ke P4 Pusat untuk PHK massal. 
Banyak upaya yang dapat dilakukan agar tidak terjadinya pemutusan hubungan kerja apalagi pada masa pandemi Covid-19 ini. Namun di Undang-Undang Cipta Kerja sendiri tidak mengatur agar pemutusan hubungan kerja tidak terjadi melainkan mengatur agar pemutusan hubungan kerja dilakukan atas kesepakatan antara pengusaha/pemberi kerja dengan pekerja/buruh.

\section{d. Konsep Perlindungan Hukum Terhadap Pemutusan Hubungan Kerja Pada Masa Pandemi Covid-19 Menurut Undang-Undang Nomor 11 Tahun 2020 Tentang Cipta Kerja}

Di tengah kondisi pandemi yang kita hadapi ini, Undang-Undang Cipta Kerja pun di sahkan. Dimana diharapkan bahwa Undang-Undang Cipta Kerja ini dapat menjawab beberapa permasalahan sektor ketenagakerjaan saat ini termasuk perlindungan hukum terhadap buruh yang mendapatkan pemutusan hubungan kerja akibat Covid-19 ini. Namun ternyata UndangUndang Cipta Kerja juga tak mengatur secara khusus perlindungan hukum terhadap buruh yang di PHK karena wabah penyakit pada masa pandemi seperti saat ini.

Pengusaha atau pemberi kerja boleh melakukan PHK harus berdasarkan alasan-alasan yang terdapat di dalam praturan perundang-undangan dan tidak dilakukan secara sepihak. Dalam ketentuan Pasal 156 ayat (1) Undang-Undang Cipta Kerja, ketika terjadi pemutusan hubungan kerja, maka perusahaan/pemberi kerja wajib membayar uang pesangon dan/atau uang penghargaan masa kerja dan uang penggantian hak yang seharusnya diterima. Penjelasan terkait uang pesangon dan/atau uang penghargaan masa kerja dan uang penggantian hak yang seharusnya diterima di tegaskan dalam Pasal 156 ayat (2), (3) dan (4) Undang-Undang Cipta Kerja sebagai berikut:

Pasal 156 ayat (2) "Uang pesangon sebagaimana dimaksud pada ayat (1) diberikan paling banyak sesuai ketentuan sebagai berikut:
a. masa kerja 3 (tiga) tahun atau lebih tetapi kurang dari 6 (enam) tahun, 2 (dua) bulan upah
b. masa kerja 6 (enam) tahun atau lebih tetapi kurang dari 9 (sembilan) tahun, 3 (tiga) bulan upah
c. masa kerja 9 (sembilan) tahun atau lebih tetapi kurang dari 12 (dua belas) tahun, 4 (empat) bulan upah
d. masa kerja 12 (duabelas) tahun atau lebih tetapi kurang dari 15 (lima belas) tahun, 5 (lima) bulan upah
e. masa kerja 15 (lima belas) tahun atau lebih tetapi kurang dari 18 (delapan belas) tahun, 6 (enam) bulan upah
f. masa kerja 18 (delapan belas) tahun atau lebih tetapi kurang dari 21 (dua puluh satu) tahun, 7 (tujuh) bulan upah
g. masa kerja 21 (dua puluh satu) tahun atau lebih tetapi kurang dari 24 (dua puluh empat) tahun, 8 (delapan) bulan upah
h. masa kerja 24 (dua puluh empat) tahun atau lebih, 10 (sepuluh) bulan upah."

Pasal 156 ayat (3) “Uang penghargaan masa kerja sebagaimana dimaksud pada ayat (1) diberikan paling banyak sesuai ketentuan sebagai berikut:

a. masa kerja 3 (tiga) tahun atau lebih tetapi kurang dari 6 (enam) tahun, 2 (dua) bulan upah

b. masa kerja 6 (enam) tahun atau lebih tetapi kurang dari 9 (sembilan) tahun, 3 (tiga) bulan upah 
c. masa kerja 9 (sembilan) tahun atau lebih tetapi kurang dari 12 (dua belas) tahun, 4 (empat) bulan upah

d. masa kerja 12 (duabelas) tahun atau lebih tetapi kurang dari 15 (lima belas) tahun, 5 (lima) bulan upah

e. masa kerja 15 (lima belas) tahun atau lebih tetapi kurang dari 18 (delapan belas) tahun, 6 (enam) bulan upah

f. masa kerja 18 (delapan belas) tahun atau lebih tetapi kurang dari 21 (dua puluh satu) tahun, 7 (tujuh) bulan upah

g. masa kerja 21 (dua puluh satu) tahun atau lebih tetapi kurang dari 24 (dua puluh empat) tahun, 8 (delapan) bulan upah

h. masa kerja 24 (dua puluh empat) tahun atau lebih, 10 (sepuluh) bulan upah."

Pasal 156 ayat (4) "Uang penggantian hak yang seharusnya diterima sebagaimana dimaksud pada ayat (1) meliputi:

a. cuti tahunan yang belum diambil dan belum gugur

b. biaya atau ongkos pulang untuk pekerja/buruh dan keluarganya ke tempat dimana pekerja/buruh diterima bekerja

c. hal-hal lain yang ditetapkan dalam perjanjian kerja, peraturan perusahaan atau perjanjian kerja bersama.

Pandemi Covid-19 ini tak hanya berdampak pada sektor ketenagakerjaan di Indonesia. Namun hal itu juga memberi dampak bagi negara-negara lainnya seperti singapura dan malaysia. Berikut penulis melakukan perbandingan perlindungan upah dan status bagi pekerja/buruh antara Malaysia dan Singapura, dikutip dari Webinar Dampak Pandemi Covid-19 Terhadap Sektor Ketenagakerjaan Di Indonesia dalam Jurnal Perlindungan Status Kerja Dan Pengupahan Tenaga Kerja Dalam Situasi Pandemi Covid-19 Berdasarkan Perspektif Pembaharuan Hukum, Administrative Law \& Governance Jurnal Fakultas Hukum Universitas Diponegoro ${ }^{9}$ :

Tabel 1. Perbandingan Perlindungan Upah dan Status Di Negara Lain

\begin{tabular}{|c|c|c|}
\hline Singapura & Malaysia & Indonesia \\
\hline 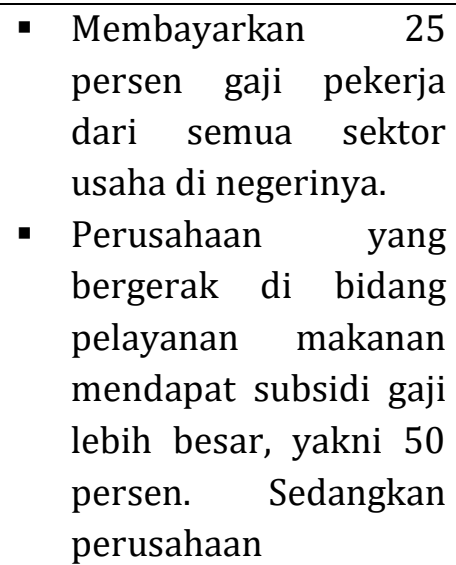 & $\begin{array}{l}\text { - Memberi subsidi gaji } \\
\text { besaran bervariasi, sesuai } \\
\text { jumlah } \\
\text { karyawan yang dimiliki } \\
\text { perusahaan. Rinciannya } \\
\text { adalah: } \\
\text { 1) Karyawan lebih dari } \\
200 \text { orang: subsidi } \\
\text { gaji RM600 atau } \\
\text { sekitar Rp2,2 juta } \\
\text { per orang. }\end{array}$ & $\begin{array}{l}\text { Dikeluarkannya } \\
\text { Surat Edaran } \\
\text { Menteri } \\
\text { Ketenagakerjaan } \\
\text { M/3/HK.04/III/2020 } \\
\text { Tentang } \\
\text { Perlindungan } \\
\text { Pekerja/Buruh Dan } \\
\text { Kelangsungan Usaha } \\
\text { Dalam } \\
\text { Rangka Pencegahan }\end{array}$ \\
\hline
\end{tabular}

${ }^{9}$ Kanyaka Prajnaparamitha dan Mahendra Ridwanul Ghoni, Perlindungan Status Kerja Dan Pengupahan Tenaga Kerja Dalam Situasi Pandemi Covid-19 Berdasarkan Perspektif Pembaharuan Hukum, Fakultas Hukum Universitas Diponegoro, Administrative Law \& Governance Jurnal, Vol. 3 Issue 2, Juni 2020 (Dr. Asri Wijayanti, Materi Webinar Dampak Pandemi Covid-19 Terhadap Sektor Ketenagakerjaan Di Indonesia ). 


\begin{tabular}{|c|c|c|}
\hline $\begin{array}{l}\text { pariwisata, yang } \\
\text { paling terpukul } \\
\text { akibat pandemic } \\
\text { Covid-19, mendapat } \\
\text { subsidi gaji } 75 \text { persen. } \\
\text { Bantuan besar ini } \\
\text { bertujuan untuk } \\
\text { mengurangi } \\
\text { pengeluaran gaji } \\
\text { perusahaan, } \\
\text { membantu } \\
\text { perusahaan } \\
\text { mempertahankan } \\
\text { pekerja mereka. } \\
\text { Gugatan pailit } \\
\text { karena hutang yang } \\
\text { tak terbayar juga } \\
\text { dinaikkan dari } \\
\$ 15.000 \quad \text { menjadi } \\
\$ 60.000 \text { singapura. }\end{array}$ & $\begin{array}{l}\text { 2) Karyawan } 76-200 \\
\text { orang: subsidi gaji } \\
\text { RM800 atau sekitar } \\
\text { Rp2,9 juta per orang. } \\
\text { 3) Karyawan } 1-75 \\
\text { orang: subsidi gaji } \\
\text { RM1.200 atau sekitar } \\
\text { Rp4,4 juta per orang. }\end{array}$ & 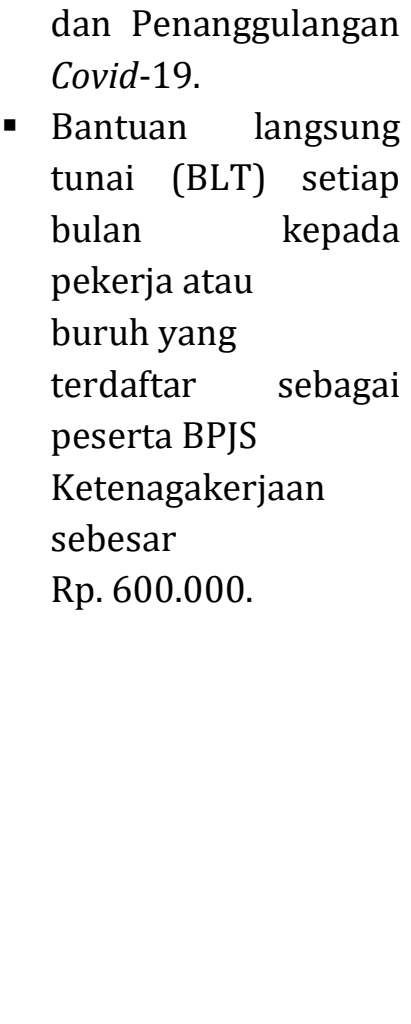 \\
\hline
\end{tabular}

Sumber : Dikutip dari beberapa sumber (Webinar Dampak Pandemi Covid-19 Terhadap Sektor Ketenagakerjaan Di Indonesia dalam Jurnal Perlindungan Status Kerja Dan Pengupahan Tenaga Kerja Dalam Situasi Pandemi Covid-19 Berdasarkan Perspektif Pembaharuan Hukum, Administrative Law \& Governance Jurnal Fakultas Hukum Universitas Diponegoro dan Kementrian Ketenagakerjaan .

Dalam beberapa kasus saat ini di Indonesia, banyak perusahaan yang tidak sanggup membayar upah atau gaji para pekerja/buruh diakibatkan perusahaan yang mengalami kerugian dan tidak mendapat pemasukan pada masa pandemi. Maka dari itu PHK merupakan jalan terakhir yang harus di tempuh perusahaan. Pemerintah mengeluarkan Surat Edaran Menteri Ketenagakerjaan Nomor M/3/HK.04/III/2020 Tentang Perlindungan Pekerja/Buruh Dan Kelangsungan Usaha Dalam Rangka Pencegahan dan Penanggulangan Covid-19 untuk memberikan perlindungan hukum terhadap para pekerja/buruh. Namun, dalam Surat Edaran Menteri Ketenagakerjaan tersebut hanya memberi perlindungan hukum terhadap pekerja/buruh yang terkena penyakit Covid-19 atau Orang Dalam Pemantauan (ODP) terkait Covid-19 sehingga pekerja/buruh yang tidak termasuk dalam ODP atau yang tidak terjangkit virus corona yang mendapatkan pemutusan hubungan kerja secara terpaksa akibat dampak dari Covid-19 sama sekali tidak diatur perlindungan hukumnya serta pemenuhan haknya dalam Surat Edaran Menteri Ketenagakerjaan tersebut. Bantuan Langsung Tunai pun hanya diberikan pemerintah terhadap peserta yang terdaftar sebagai BPJS Ketenagakerjaan.

Maka dari itu, PHK yang dilakukan secara terpaksa oleh perusahaan dikarenakan pemasukan perusahaan yang menurun secara drastis dalam masa pandemi ini dapat dikategorikan sebagai perusahaan yang melakukan efisiensi dengan ketentuan membayar pesangon sesuai yang di atur dalam Pasal 164 ayat (3) Undang-Undang Ketenagakerjaan. Namun setelah dikeluarkannya Undang-Undang Cipta Kerja, ketentuan Pasal 164 pun dihapus. Undang-Undang Cipta Kerja pun mengatur dalam hal terjadinya pemutusan hubungan kerja maka maka perusahaan/pemberi kerja wajib membayar uang pesangon dan/atau uang 
penghargaan masa kerja dan uang penggantian hak yang seharusnya diterima sebagai bentuk perlindungan hukum terhadap buruh.

\section{KESIMPULAN}

Berdasarkan uraian di atas, maka penulis menarik kesimpulan yaitu Konsep perlindungan hukum terhadap buruh yang mendapatkan pemutusan hubungan kerja akibat Covid-19 menurut Undang-Undang Nomor 11 Tahun 2020 tentang Cipta bertumpu pada keadilan yang sama rata, artinya ketika terjadinya pemutusan hubungan kerja yang telah disepakati antara pemberi kerja dan buruh maka pengusaha/pemberi kerja wajib memenuhi hak para buruh yang diberhentikan berupa pesangon sesuai dengan ketentuan Pasal 156 ayat (1). Kedua Undang-Undang ini memiliki persamaan yaitu sama-sama berusaha memberikan keadilan baik kepada buruh ataupun pemberi kerja.

\section{DAFTAR PUSTAKA}

Raharjo, S. 2000. Ilmu Hukum, Bandung: Citra Aditya Bhakti.

Prajnaparamitha, K. dan Ghoni, M.R, "Perlindungan Status Kerja Dan Pengupahan Tenaga Kerja Dalam Situasi Pandemi Covid-19 Berdasarkan Perspektif Pembaharuan Hukum”, (Fakultas Hukum Universitas Diponegoro, Administrative Law \& Governance Jurnal, Vol. 3 Issue 2).

Gum Setyadi, D.M, "Pendampingan Upaya Pendekatan Ketaatan Masyarakat Terhadap Surat Edaran No. 434/572/DKIS/2020 Pembatasan Jam Operasional Di Desa Sidakarya”, Uurnal Pengabdian Masyarakat, Vol. I, No. 3, hal. 160-166).

Setiono, 2004, Rule Of Law, Surakarta: Magister Ilmu Hukum Program Pascasarjana Universitas Sebelas Maret. 